\title{
Integrasi Aplikasi Desktop dan Mobile pada Koperasi Karyawan Mitra Makmur
}

\author{
Muchamad Akbar Nurul Adzan', De Rosal Ignatius Moses Setiadi², Desi Purwanti \\ Kusumaningrum ${ }^{3}$, Eko Hari Rachmawanto ${ }^{4}$, Christy Atika Sari ${ }^{5}$ \\ Program Studi Ilmu Komputer; Universitas Dian Nuswantoro Semarang \\ Jl. Nakula I No 5-11, Pendrikan Kidul, Semarang Tengah, Kota Semarang. Telp. 024-3517261 \\ e-mail: ${ }^{1} 111201307488 @$ mhs.dinus.ac.id, ${ }^{2}$ moses@dsn.dinus.ac.id, ${ }^{3}$ desi.purwanti@dsn.dinus.ac.id, \\ ${ }^{4}$ eko.hari@dsn.dinus.ac.id, 5 atika.sari@dsn.dinus.ac.id
}

\begin{abstract}
Abstrak
Koperasi Karyawan Mitra Makmur memiliki aplikasi Dekstop untuk menunjang kegiatannya. Walaupun demikian terdapat kendala dimana kurang praktisnya aplikasi berbasis desktop karena hanya dapat dibuka melalui komputer saja. Saat ini banyak anggota koperasi yang menggunakan perangkat mobile, hal ini melatarbelakangi perlunya pembuatan aplikasi berbasis mobile. Maka dibutuhkan aplikasi mobile dibutuhkan sebagai solusi untuk memudahkan akses. Karena terdapat dua macam aplikasi, maka keduannya harus diintegrasikan. Salah satu cara untuk mengintegrasikan kedua aplikasi tersebut dengan web service dan backend sebagai sistem manajemen konten pada aplikasi mobile. JSON (Javascript Object Notation) diusulkan sebagai perangkat pertukaran data. JSON dipilih karena prosesnya yang cepat dan ringan. Untuk mengukur kinerja web service pada proses integrasi, maka perlu dianalisis dan diukur kebutuhan waktu request HTTP sampai didapatkan response HTTP. Terdapat dua cara pengukuran lama waktu request web service yaitu dengan pengujian secara online dan lokal. Masing-masing pengujian request dilakukan sebanyak lima kali dimana didapat rata-rata 1192 ms. Waktu yang dibutuhkan tersebut relatif wajar dan dapat disimpulkan bahwa proses integrasi dapat berjalan dengan baik.
\end{abstract}

Kata kunci: Web Service, Javascript Object Notation, Waterfall, Backend.

\begin{abstract}
Koperasi Karyawan Mitra Makmur has a desktop application to support its activities. However, there are obstacles where the less practical desktop-based applications because it can only be opened through a computer only. Currently, many members of cooperatives who use mobile devices, this is behind the necessity of making a mobile-based application. So required mobile application needed as a solution to easy access. Because there are two kinds of applications, the two must be integrated. One way to integrated both applications with web service and backend as a content management system in mobile applications. JSON (Javascript Object Notation) is proposed as a data exchange device. JSON was chosen because the process is fast and light. To measure the performance of web services on the integration process, it needs to be analyzed and measured the need of HTTP request time to get response HTTP. There are two ways of measuring the duration of a web service request is by testing online and local. Each request test is done five times, which is an average of $1192 \mathrm{~ms}$. The time required is relatively reasonable and can be concluded that the integrity process can run well.
\end{abstract}

Keywords: Web Service, Javascript Object Notation, Waterfall, Backend.

\section{Pendahuluan}

Koperasi Karyawan Mitra Makmur saat ini telah memiliki aplikasi desktop yang berguna sebagai penunjang dalam kegiatan yang berkaitan dengan koperasi. Tetapi aplikasi ini tidak dapat dimanfaatkan secara maksimal mengingat ketika menggunakan aplikasi desktop dibutuhkan komputer atau laptop untuk membukanya sehingga pengecekan tidak dapat dilakukan setiap saat. Dalam upaya optimalisasi penggunaan aplikasi khususnya dalam menyajikan informasi yang lebih up to date bagi karyawan atau peserta koperasi yang memiliki mobilitas tinggi, maka dibutuhkan pengembangan aplikasi mobile. Aplikasi mobile tentunya tidak serta merta menghilangkan fungsi aplikasi desktop, sehingga aplikasi desktop yang telah ada tetap dapat digunakan khususnya bagi admin koperasi. Karena nantinya akan terdapat dua basis aplikasi, maka kedua aplikasi perlu diintegrasikan. Untuk mengintegrasikan kedua aplikasi tersebut dibuat 
web service dan backend berbasis web sebagai manajemen konten dan data yang ada pada aplikasi mobile[1]. Sehingga dapat terbentuk sistem yang saling terhubung yaitu antara aplikasi desktop, web dan mobile.

Web service adalah serangkaian komponen peranti lunak yang bertukar informasi antara satu sama lain dengan bebas menggunakan standar komunikasi web dan bahasa standar [2]. Web service dapat bertukar informasi pada dua sistem yang berbeda, terlepas dari sistem operasi dan bahasa yang digunakan. Web service dirancang untuk mendukung interaksi yang bisa beroperasi machine-to-machine diatas jaringan. Backend adalah halaman dashboard admin atau sering disebut dengan CMS (Content Management System) yang berguna sebagai tempat perubahan informasi atau konten pada suatu aplikasi dengan cara masuk sebagai administrator [3].

Pada penelitian yang dilakukan oleh Martinus Raditia Sigit Surendra tahun 2014 yang berjudul "Implementasi PHP Web Service Sebagai Penyedia Data Aplikasi Mobile" [4]. Hasil penelitian dengan pemanggilan method menggunakan XML (Extensible Markup Language) lebih rumit dan memiliki ukuran file besar dibandingkan dengan HTTP (Hypertext Transfer Protocol) request dengan penambahan layer PHP yang diimplementasikan dalam aplikasi mobile dan dengan menggunakan format data JSON (Javascript Object Notation) dinilai memiliki ukuran file kecil dan response yang diterima lebih cepat.

Pada penelitian yang dilakukan oleh Ilhamsyah tahun 2011 yang berjudul "Implementasi Web Service Sistem Integrasi Data Menggunakan Teknik Replikasi Data Pada Inventarisasi Bangunan Pemerintah" [5]. Hasil dari penelitian di sini adalah proses integrasi menggunakan web service pada BPKAD kota atau kabupaten dengan melalui service provider yang diakses oleh client dan kemudian dilakukan proses replikasi data ke BPKAD provinsi Kalimantan Barat. Teknologi web service dengan menggunakan teknik replikasi data sangat efektif pada transaksi data, karena method dari web service akan secara otomatis memproses data yang dikirim ke server.

Berdasarkan beberapa penelitian terkait di atas maka penelitian ini mengintegrasikan aplikasi Dekstop dan Mobile pada Koperasi Karyawan Mitra Makmur. Data yang digunakan merupakan data langsung dari sumber atau pihak koperasi yaitu berupa data peserta, transaksi, tabungan, info potongan, pinjaman, simpanan dan (jaminan kesehatan) yang nantinya data akan dikirim dalam bentuk JSON dengan web service dari aplikasi desktop milik pihak Koperasi Karyawan Mitra Makmur.

\section{Metode Penelitian}

Dalam penelitian ini model atau metode yang digunakan adalah waterfall model. Pada waterfall memiliki ciri khas dimana setiap fase atau tahapan akan diselesaikan satu persatu sebelum berlanjut ke tahap atau fase berikutnya dan hasil dari tahap sebelumnya akan digunakan sebagai jalan masuk ke fase atau tahap selanjutnya [6]. Adapun proses tahapan dari waterfall pada gambar berikut.

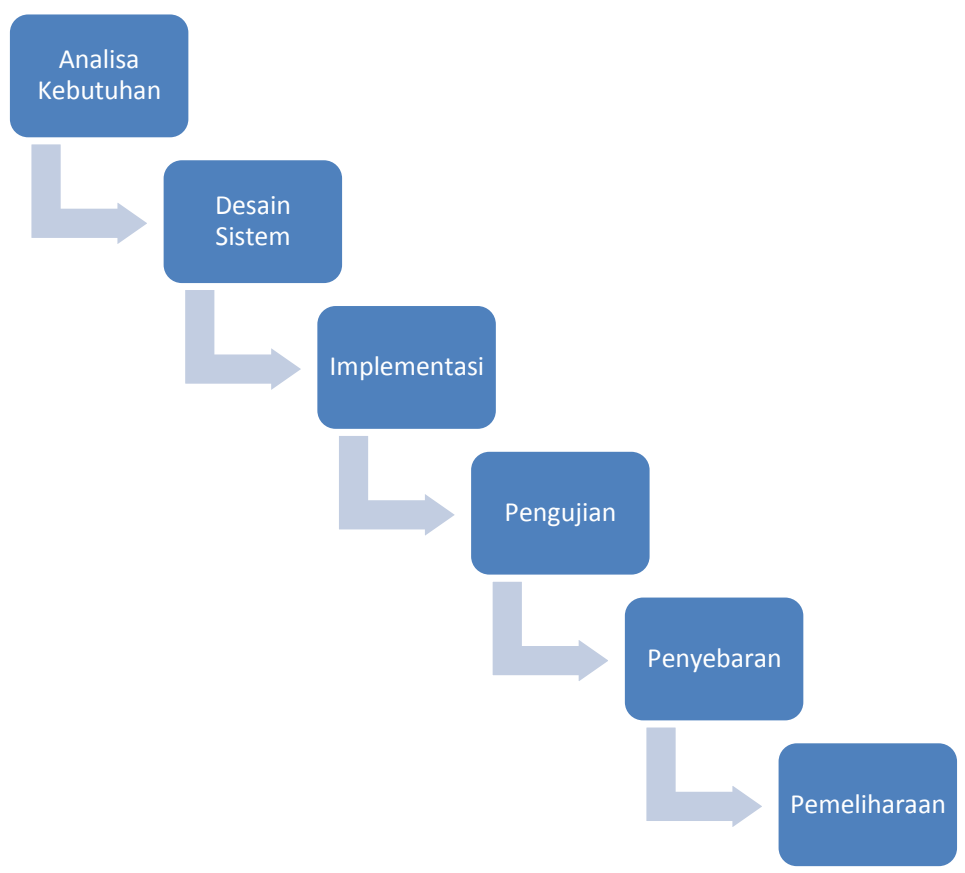

Gambar 1. Struktur model waterfall [3]. 
Proses model dari Gambar 1 yaitu adalah tahap-tahap yang ada pada model waterfall yang akan diimplementasikan dan diuji sesuai dengan spesifikasi dari sistem web service dan backend yang dibuat. Sebagai berikut proses pada masing-masing tahapan.

\subsection{Analisa Kebutuhan}

Pada tahap ini semua persyaratan atau analisa kebutuhan akan didokumentasikan. Seluruh kebutuhan dalam membuat produk harus disajikan dalam tahap ini. Kebutuhan informasi yang biasanya didapat melalui interview, survey atau diskusi.

\subsection{Desain Sistem}

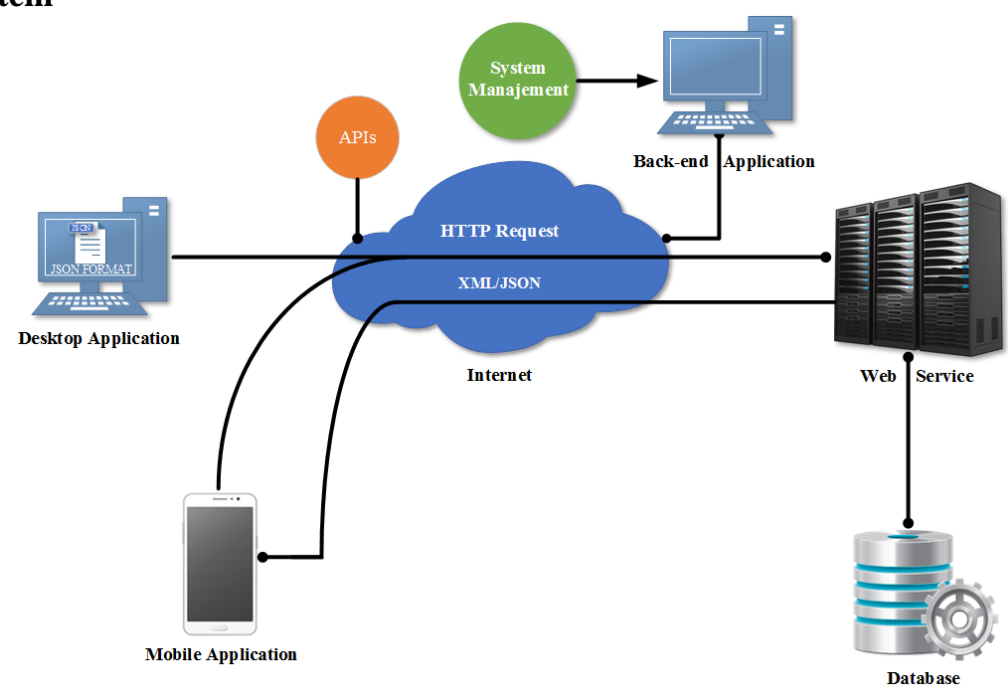

Gambar 2. Desain integrasi sistem.

Pada tahap sistem desain akan sangat membantu dalam pembuatan struktur program. Pada tahap ini menjelaskan gambaran atau alur sistem keseluruhan apa saja yang akan dikerjakan dan seperti apa tampilannya. Gambar 3 dan Gambar 4 merupakan desain sistem yang digunakan dalam pembuatan aplikasi backend dan web service.

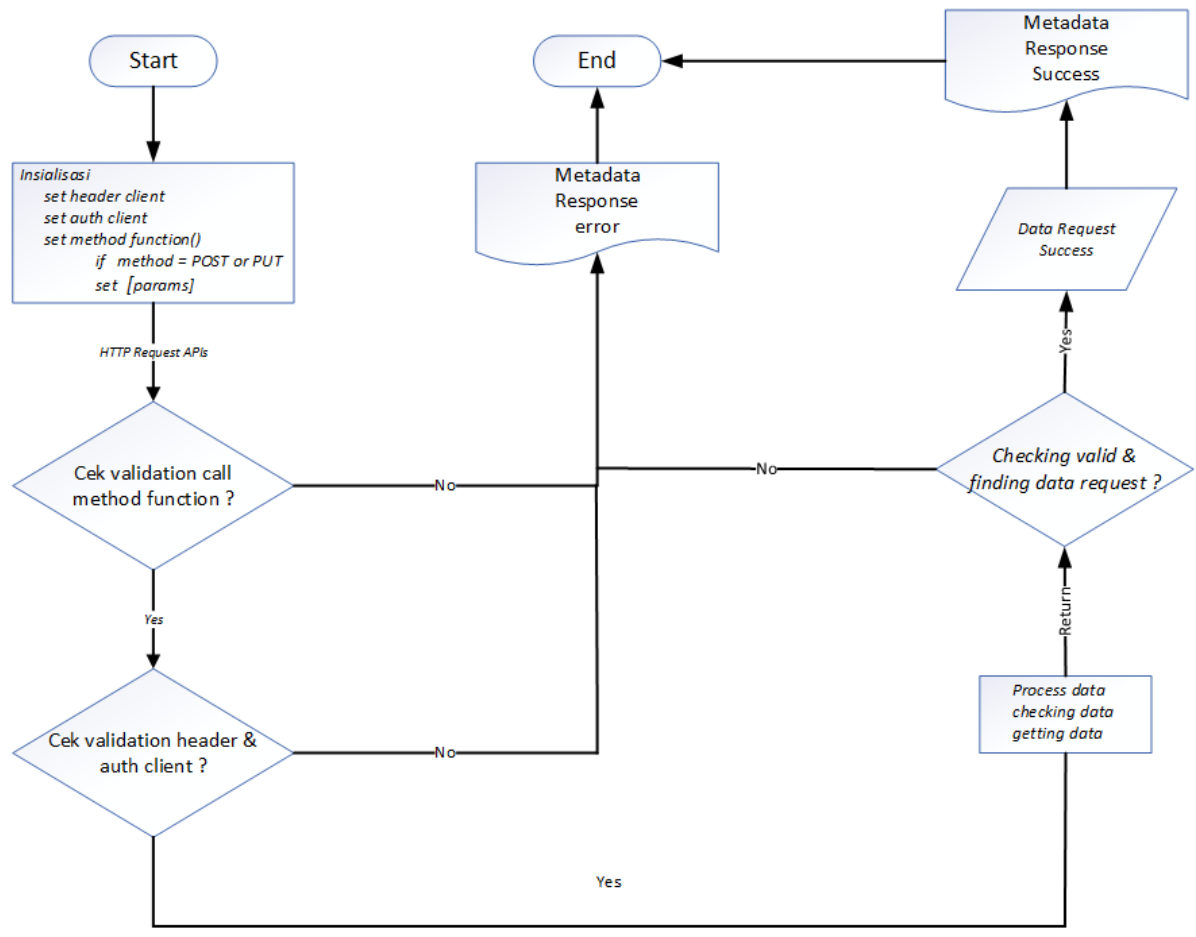

Gambar 3. Desain flowchart web service. 


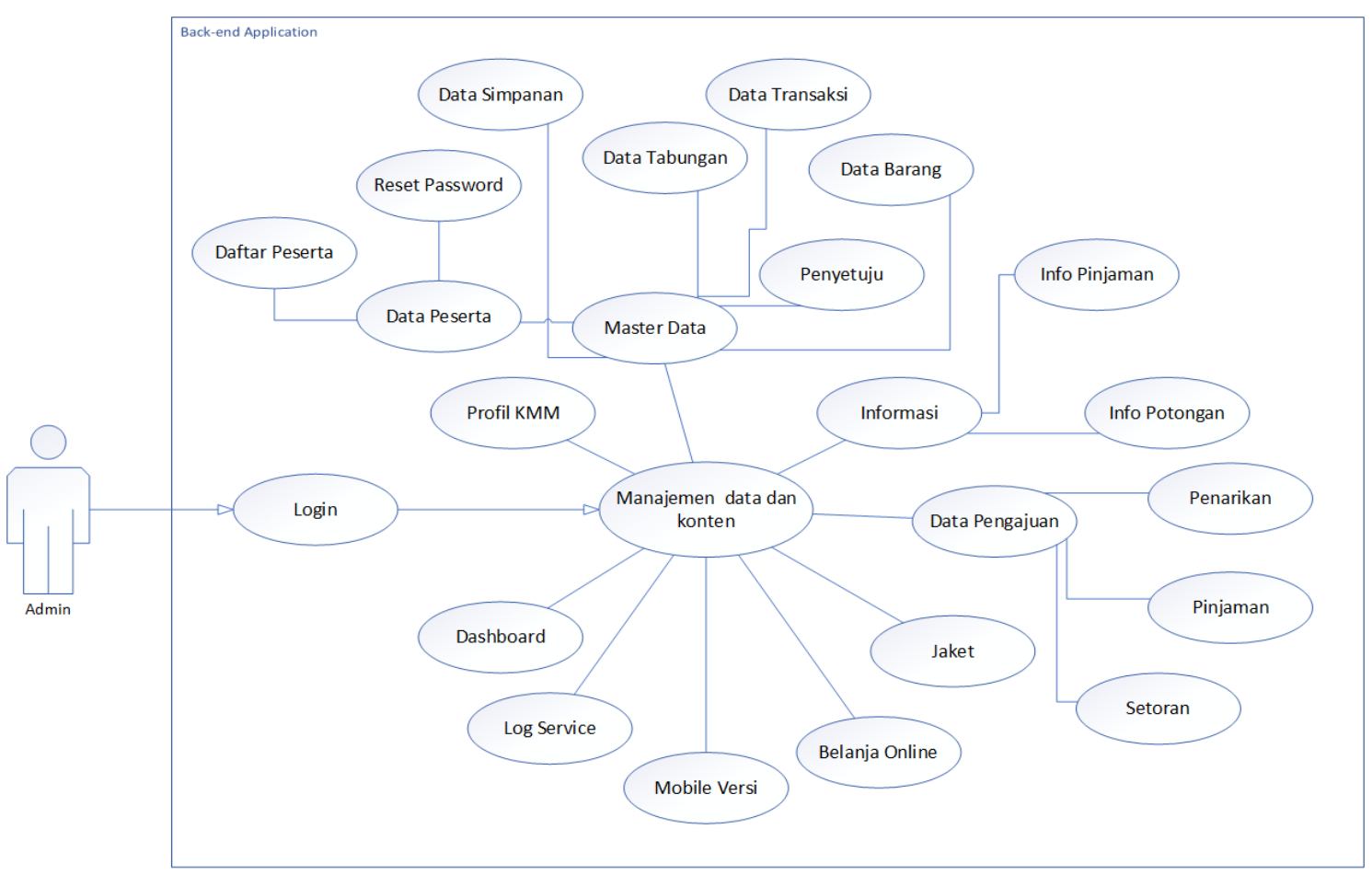

Gambar 4. Use case diagram backend.

\subsection{Implementasi}

Pada tahap implementasi desain interface akan diimplementasikan pada aplikasi dengan operating system Android, sedangkan aplikasi backend dan web service akan dibuat berbasis website menggunakan JSON.

\subsection{Pengujian}

Tahap pengujian adalah tahapan dimana setiap unit program atau aplikasi yang telah diimplementasikan diuji. Pengujian yang dilakukan pada web service yaitu menggunakan aplikasi bantuan sebagai GUI API Caller yaitu postman dan pada aplikasi backend dilakukan penambahan konten pada aplikasi mobile. Pada tahap ini akan dijelaskan secara lebih detail pada bagian hasil dan pembahasan.

\subsection{Penyebaran}

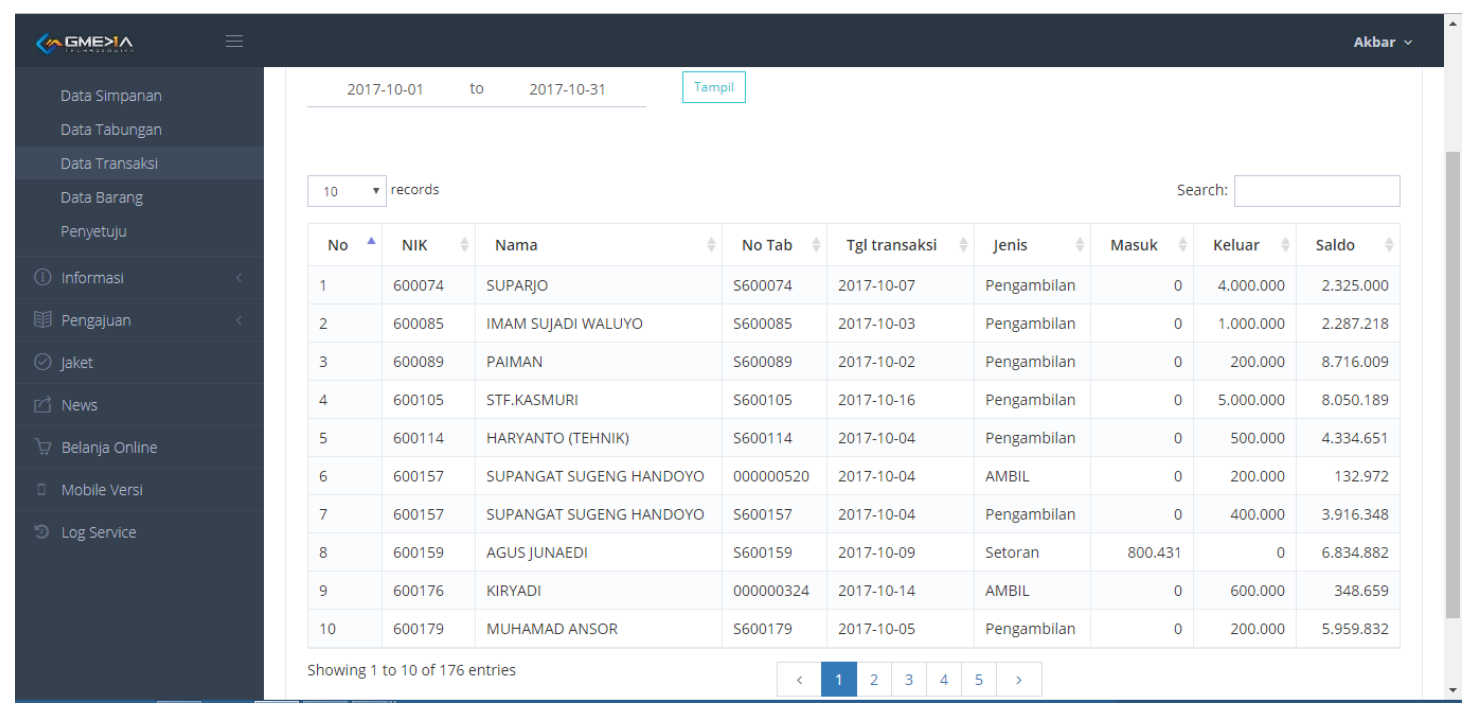

Gambar 5. Data transaksi bulan Oktober 2017. 
Pada tahap ini merupakan tahapan dimana aplikasi yang sudah diuji pada keseluruhan sistem, maka dilanjut dengan melakukan penyebaran produk pada lingkungan user Koperasi Karyawan Mitra Makmur itu sendiri. Aplikasi ini sendiri sudah di hosting pada server milik Gmedia Semarang sebagai rekan kerja dari pihak koperasi, dan aplikasi ini sudah digunakan dan berjalan sampai sekarang. Gambar 5 merupakan contoh data transaksi yang diambil dari aplikasi backend.

\subsection{Pemeliharaan}

Pada tahap pemeliharaan kondisi sistem akan terus di cek dan di-maintenance sesuai dengan kebutuhan untuk meminimalisir masalah yang ada saat sistem diimplementasikan.

\section{Hasil dan Pembahasan}

\subsection{Implementasi}

Implementasi atau penerapan kinerja aplikasi dan contoh kode (coding) pada web service dan desain interface yang ada pada aplikasi backend. Sebagai pada Gambar 6 dan 7 merupakan contoh pembuatan fungsi web servis dengan method GET dan method POST, gambar 8 merupakan contoh hasil implementasi desain interface, sedangkan pada Gambar 9 merupakan contoh implementasi web service.

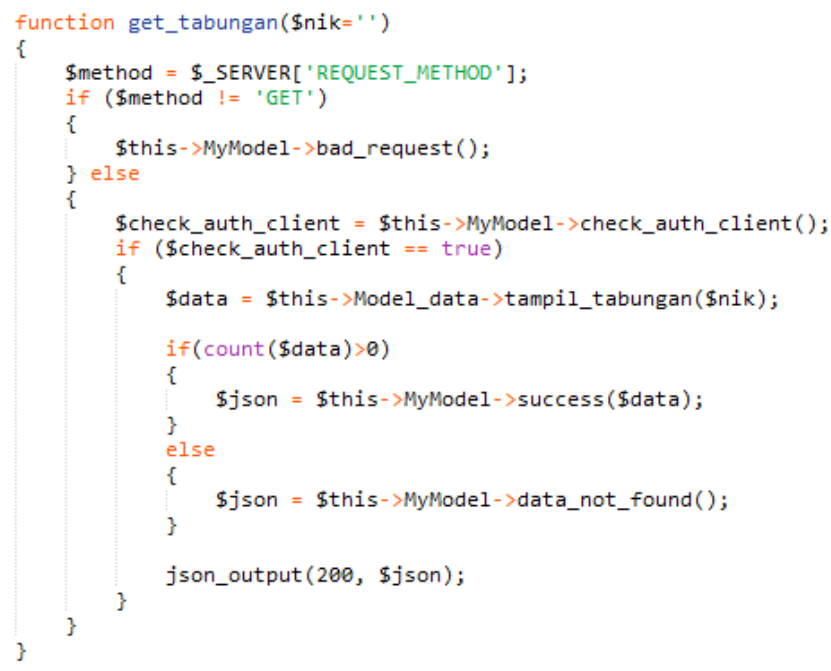

Gambar 6. Fungsi web service method get.

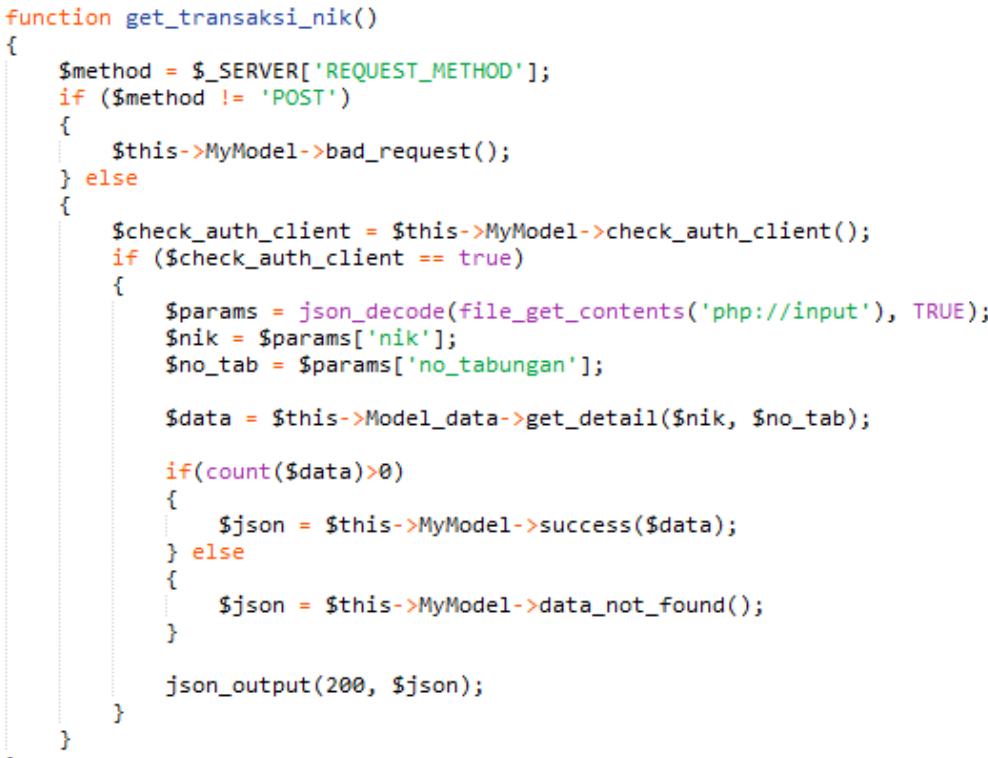

Gambar 7. Fungsi web service method post. 


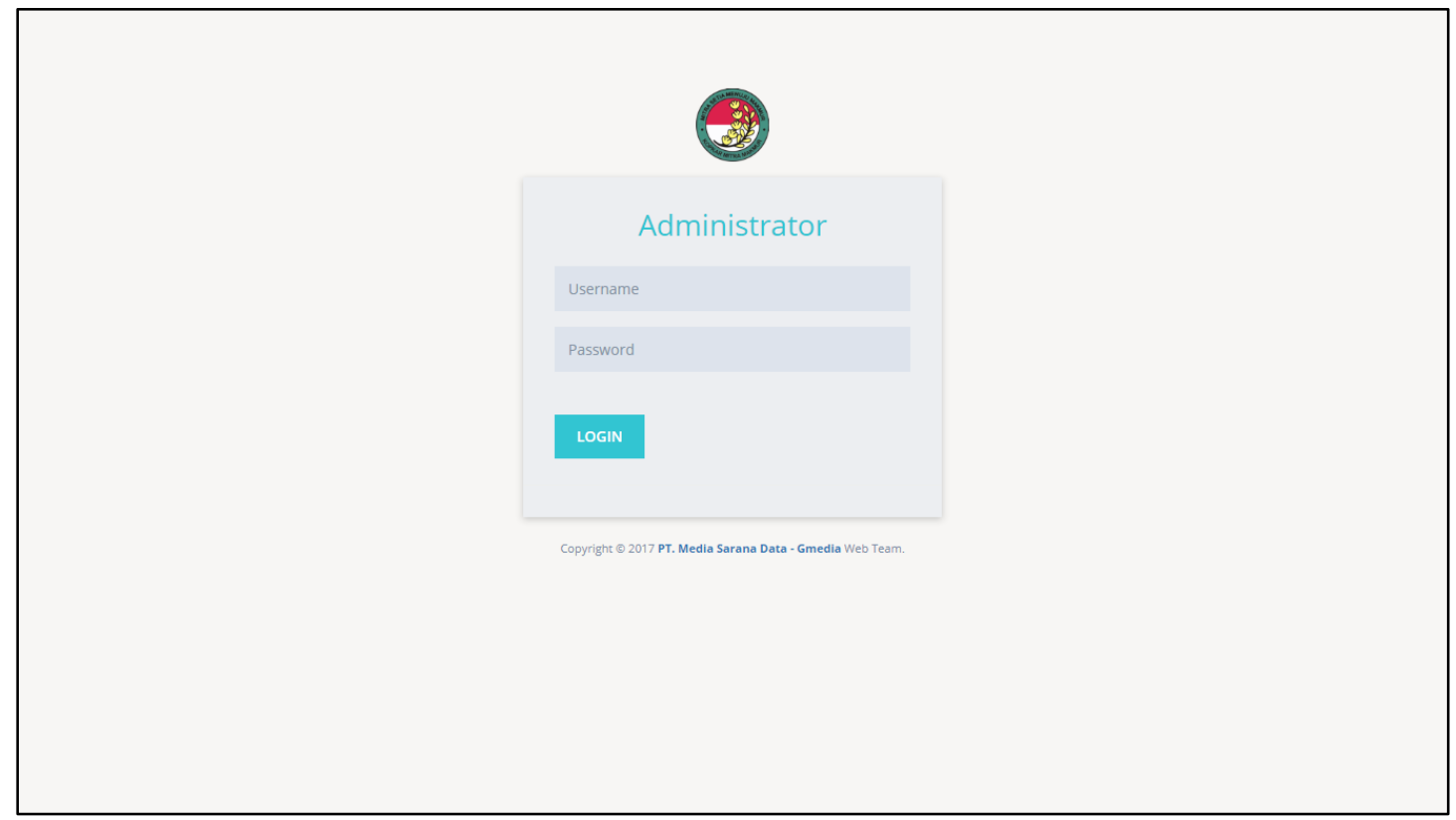

Gambar 8. Halaman login backend.

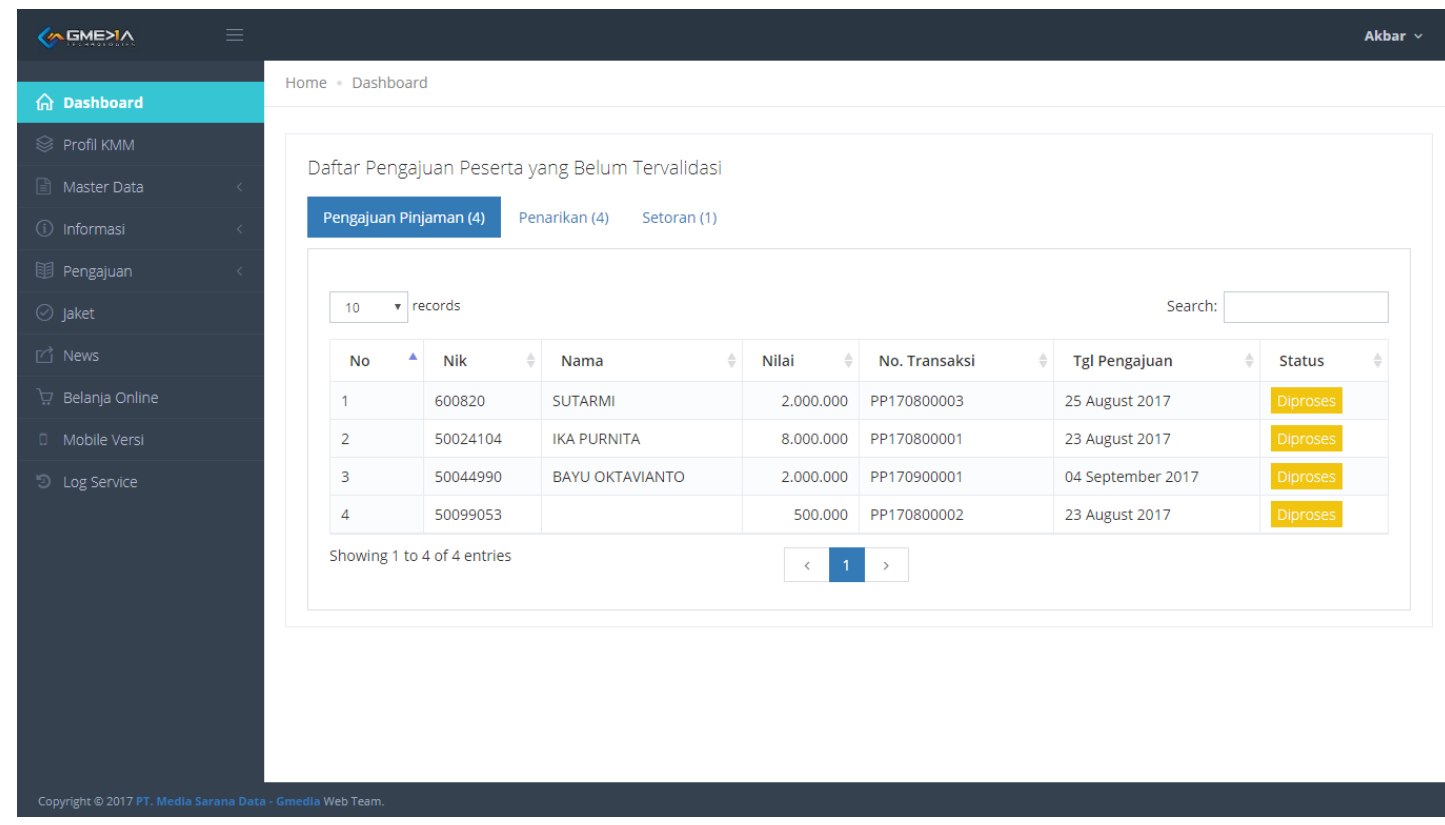

Gambar 9. Halaman dashboard backend.

\subsection{Analisis Kinerja Web Service}

Pada bagian analisis kinerja web service dilakukan guna untuk mengetahui lama waktu yang dibutuhkan dalam melakukan HTTP Request sampai mendapatkan HTTP Response. Pada analisis ini dilakukan dengan cara mengambil data dalam jumlah record yang besar dan dilakukan dengan dua tipe yaitu dengan cara local dan online. Dalam melakukan analisis web service di sini menggunakan aplikasi bantuan yaitu postman sebagai GUI tester web service. Tabel 1 merupakan daftar hasil beberapa pengujian web service secara local dan online.

Tabel 1. Daftar hasil pengujian web service.

\begin{tabular}{ccccc}
\hline Pengujian & Record & Online (ms) & Local (ms) & Selisih \\
\hline Pengujian Pertama & 1000 & 1576 & 594 & 982 \\
\hline Pengujian Kedua & 3000 & 1612 & 707 & 905 \\
\hline
\end{tabular}




\begin{tabular}{ccccc}
\hline Pengujian Ketiga & 5000 & 2542 & 1413 & 1129 \\
\hline Pengujian Keempat & 7000 & 2910 & 1855 & 1055 \\
\hline Pengujian Kelima & 9000 & 4422 & 2531 & 1891 \\
\hline
\end{tabular}

Dari hasil pengujian di atas dapat disimpulkan bahwa untuk mengukur lama waktu response yang dibutuhkan didapatkan selisih waktu rata-rata ketika melakukan request dengan cara local dan online yaitu 1192 ms (milisecond). Pada hasil pengujian menjelaskan bahwa waktu request yang lama yaitu pada bagian online, dikarenakan penggunaan request dengan online tergantung pada kecepatan internet yang digunakan. Adapun grafik yang didapatkan dari pengujian ditampilkan pada Gambar 10.

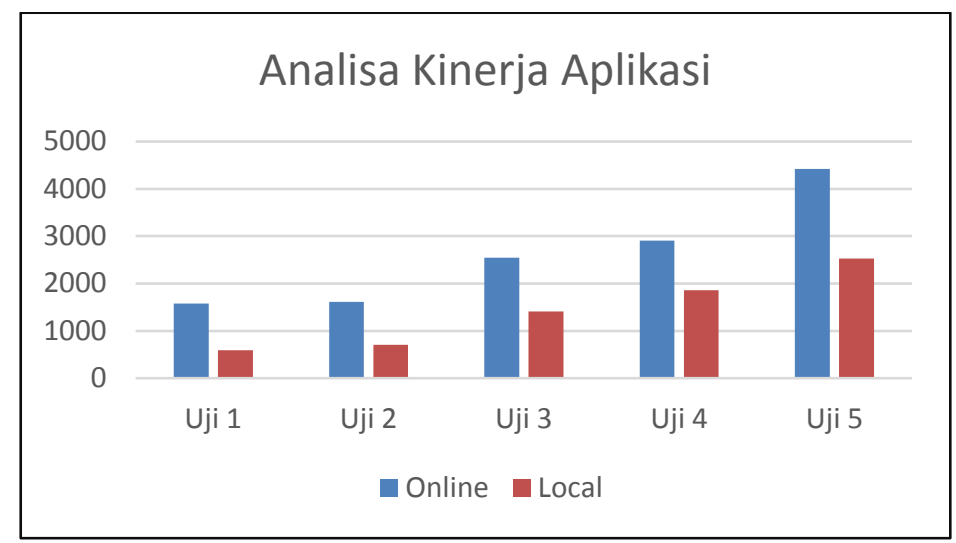

Gambar 10. Grafik hasil analisa kinerja web service.

\subsection{Pengujian}

Pada bagian ini aplikasi yang telah diimplementasikan dilakukan beberapa pengujian yang dibutuhkan. Pengujian yang dilakukan di sini berupa pengujian blackbox pada aplikasi backend dan web service. Untuk pengujian web service menggunakan aplikasi postman dengan melakukan pengiriman data dan akan ditampilkan pada aplikasi backend dan untuk pengujian aplikasi backend dilakukan dengan mengganti atau menambahkan konten dari aplikasi backend yang membuat perubahan data atau konten pada aplikasi mobile. Berikut adapun gambar pengujian yang dilakukan.

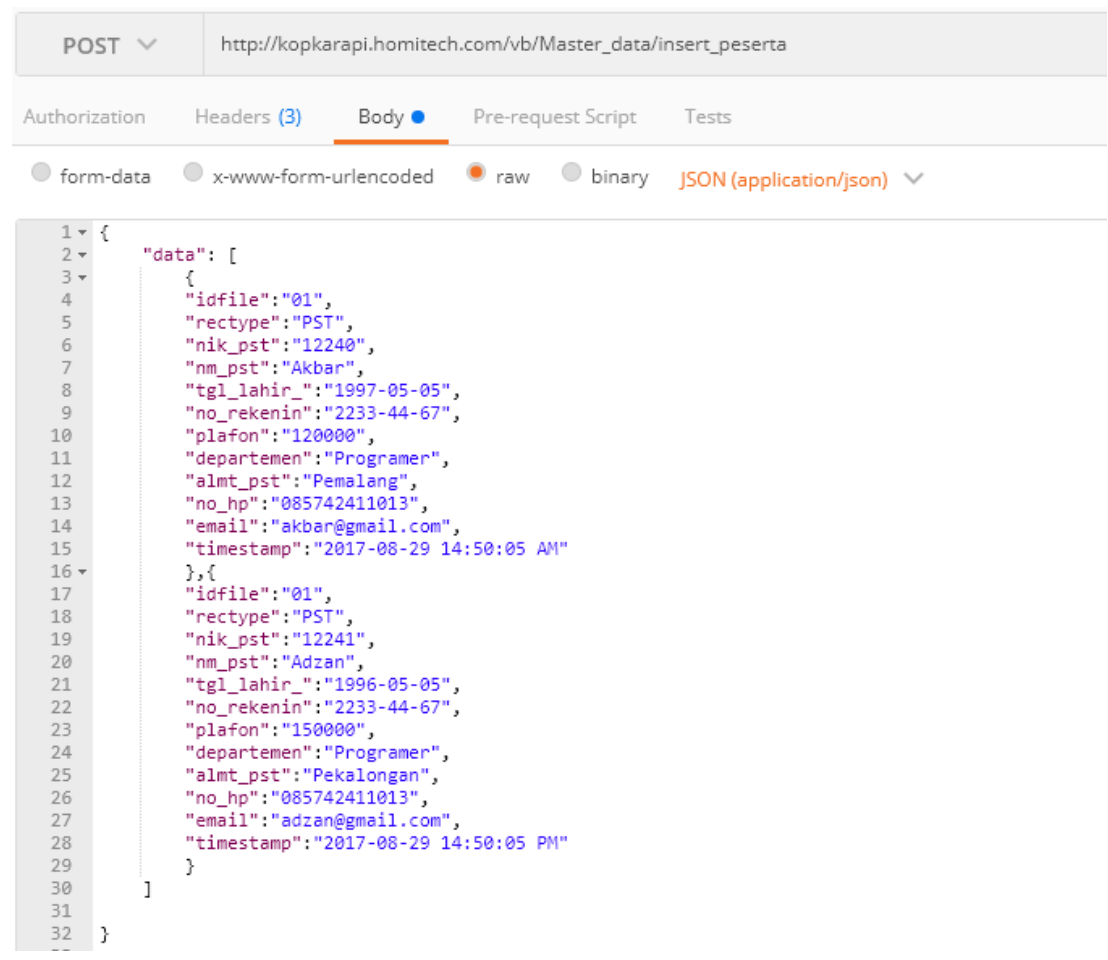

Gambar 11. Pengaturan value pada body postman. 


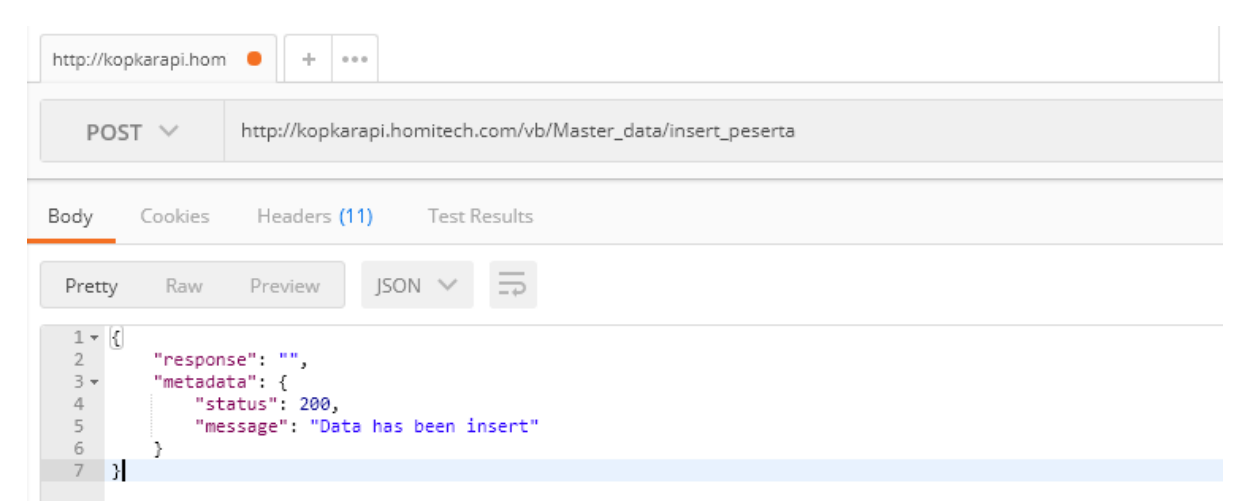

Gambar 12. Kondisi HTTP response.

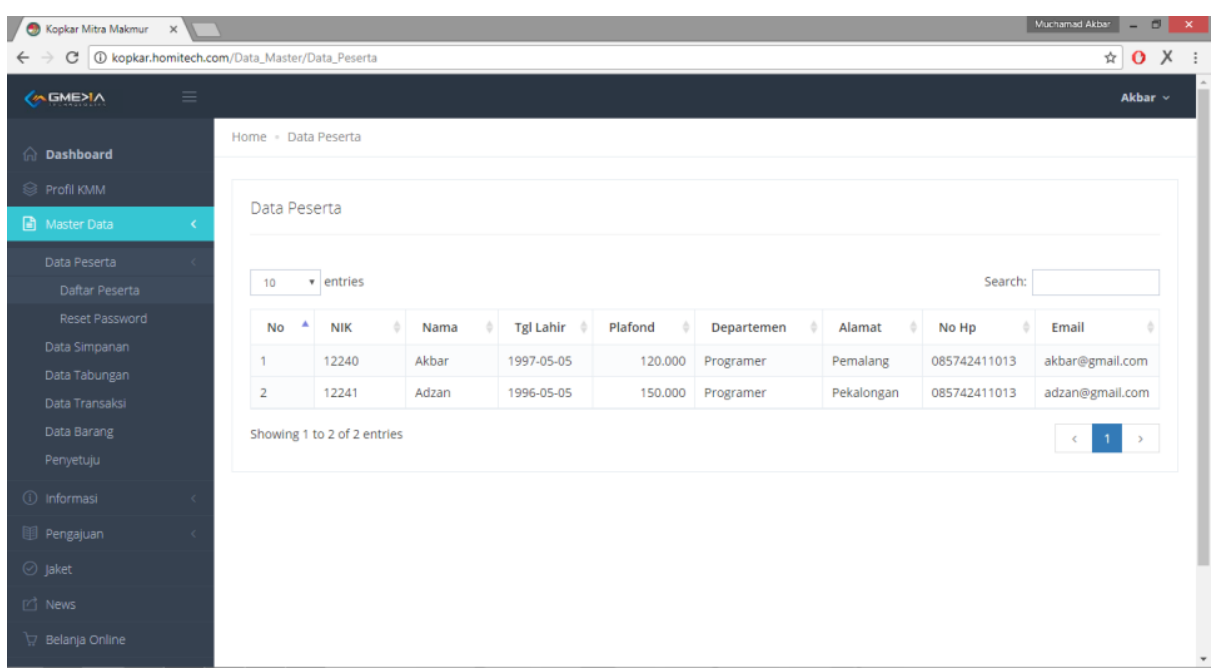

Gambar 13. Kondisi data tersimpan.

Pada pengujian web service yaitu dilakukan pengaturan awal pada postman dengan mengisi value yang akan dikirim pada body aplikasi postman terdapat pada Gambar 11 yaitu persiapan pengujian dengan mengisi value yang dikirim dan pada Gambar 12 ada kondisi response yang didapat pada saat selesai melalukan request, response yang ditujukan berupa response sukses yang menandakan pengiriman berhasil dan untuk hasil dari data yang dikirim melalui postman ada pada Gambar 13 merupakan data yang tersimpan dan ada pada aplikasi backend.

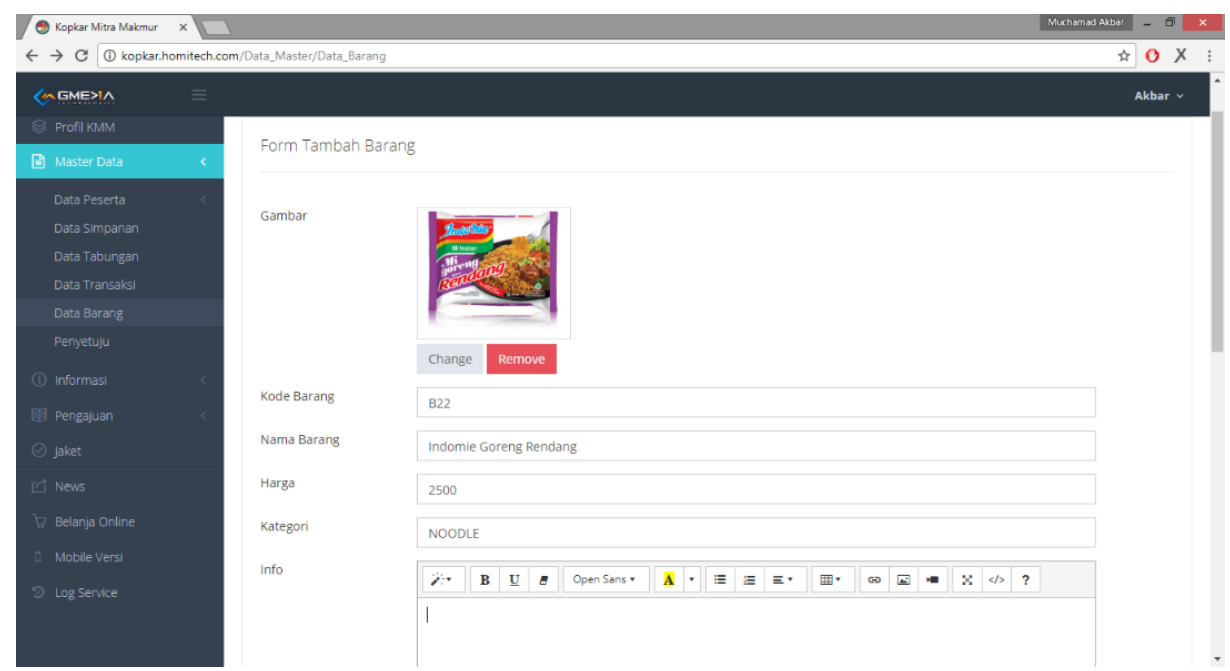

Gambar 14. Kondisi persiapan backend. 


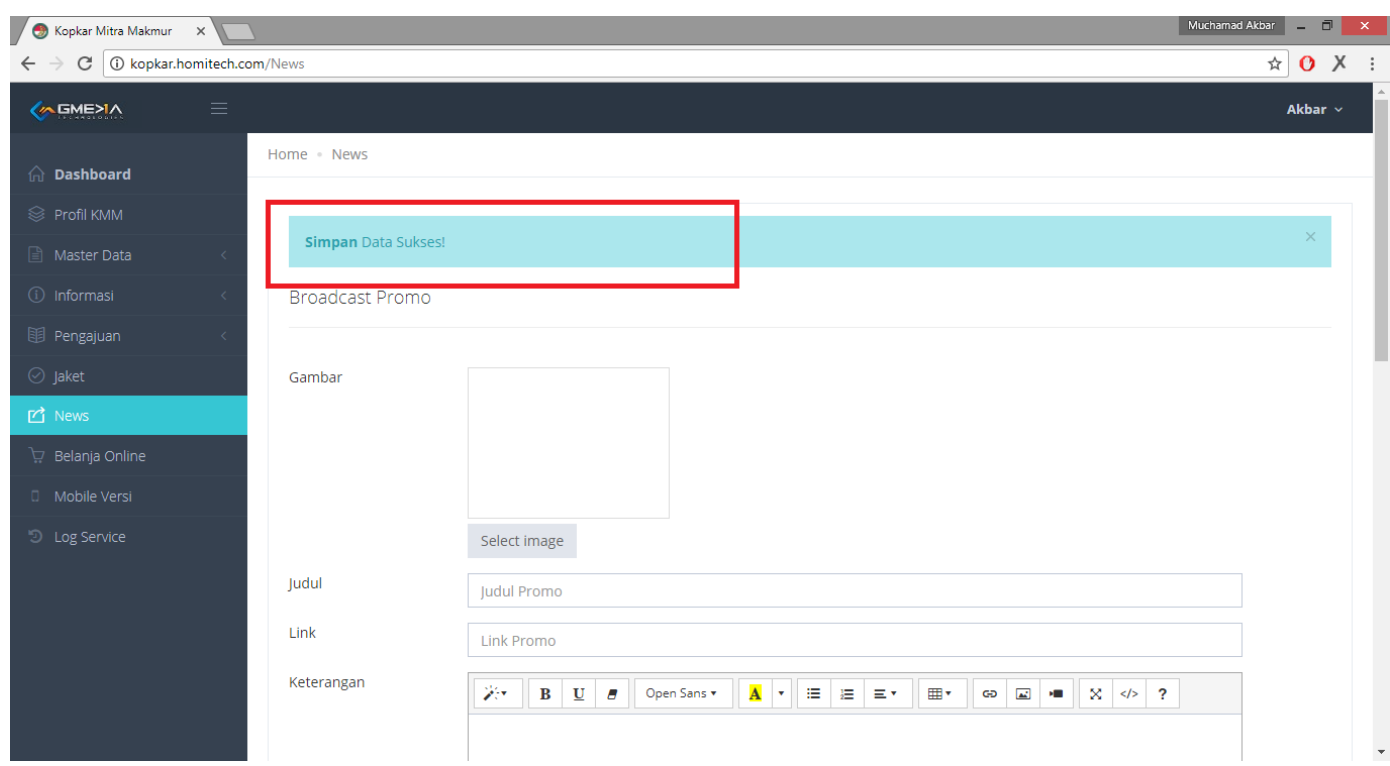

Gambar 15. Tampilan notifikasi sukses.

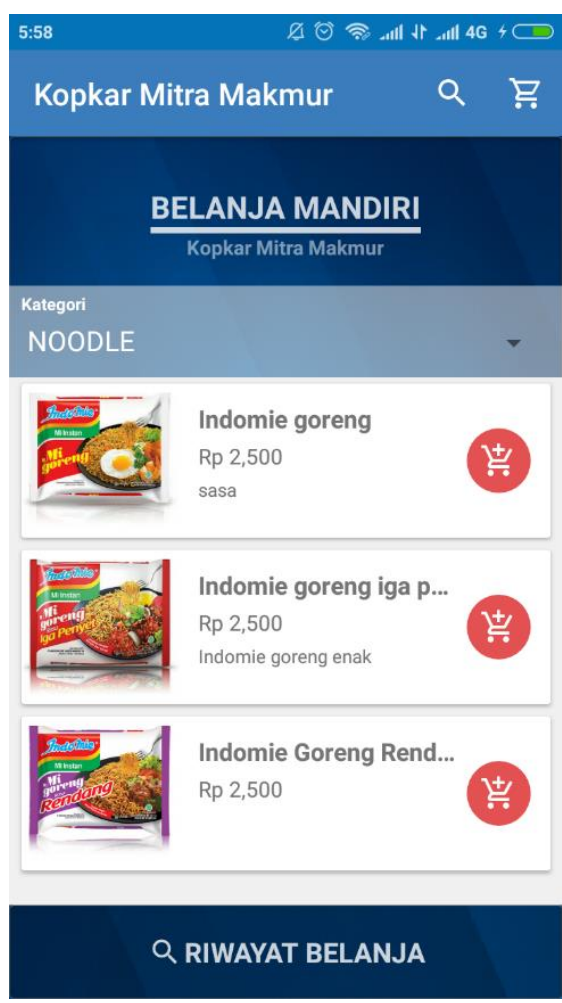

Gambar 16. Kondisi akhir pada aplikasi mobile.

Pada pengujian yang dilakukan pada aplikasi backend di sini adalah dengan melakukan penambahan data pada data barang, untuk persiapan penambahan data pada gambar 14 persiapan penambahan data barang dan kemudian simpan dan terdapat notifikasi sukses tersimpan pada gambar 15 yang menandakan gambar telah tersimpan dan untuk hasil yang berubah pada aplikasi mobile yaitu pada gambar 16. Jadi pengujian pada aplikasi backend merupakan menambah konten yang ada pada aplikasi mobile.

Perlu diketahui bahwa, aplikasi ini telah diimplementasikan dan memiliki masalah pada bagian web service apabila menerima file yang dikirim dari aplikasi desktop dalam satu pengiriman membawa jumlah record yang besar sehingga memberatkan kinerja server dikarenakan fungsi web service yang 
digunakan aplikasi desktop memiliki validasi data per record dalam setiap pengiriman data. Akan tetapi dalam kendala yang dialami ini terdapat solusi dalam mengatasi masalah yang ada yaitu dengan memanfaatkan fitur dari cpanel yaitu fitur cronjob dan melakukan penambahan tabel temporary yang dibutuhkan. Cronjobs adalah sistem penjadwalan otomatis yang dibuat menggunakan command program yang disebut crontab [7].

Jadi cara kerjanya yaitu cronjob akan mengeksekusi fungsi yang dibuat sebelumnya secara otomatis sesuai dengan pemasangan pada sistem penjadwalan cronjob. Temporary tabel digunakan untuk media penggantian tabel utama dan dengan fitur cronjob yang mengeksekusi fungsi secara otomatis untuk memindah data dari tabel temporary menuju tabel utama.

\section{Kesimpulan}

Pada penelitian disini dapat disimpulkan yaitu dalam pembuatan dan perancangan pada aplikasi backend dan web service pada Koperasi Karyawan Mitra Makmur dan kemudian dilanjut dengan tahapan pengujian yang dilakukan pada web service yaitu terdapat pengujian pengiriman data dan analisa kinerja lama waktu yang dibutuhkan pada saat melakukan request dengan cara local dan online didapatkan hasil rata-rata yaitu $1190 \mathrm{~ms}$ (milisecond). Dan pada pengujian aplikasi backend penambahan atau perubahan data pada aplikasi mobile telah berjalan dengan baik dan setelah melakukan pengujian yang dilakukan, penggunaan aplikasi backend dan web service sampai sekarang masih digunakan dan berjalan dengan lancar.

\section{Daftar Pustaka}

[1] PT. Media Sarana Data, "Info tentang Perusahaan" http://www.gmedia.net.id/pages/view/29/InfoPerusahaan, 2012.

[2] G. Alonso, F. Casati, H. Kuno and V. Machiraju, "Web Service," in Data-Centric Systems and Applications, Springer, 2004, pp. 123-149.

[3] Government of the HKSAR., "Web Content Management System," Int. J. Innov. Res. Adv. Eng., vol. 3, no. 3, pp. 51-56, 2016.

[4] M. Raditia and S. Surendra, "Implementasi PHP Web Service Sebagai Penyedia Data Aplikasi Mobile," vol. VI, no. 2, pp. 85-93, 2014.

[5] Ilhamsyah, "Implementasi Web Services Sistem Integrasi Data Menggunakan Teknik Replikasi Data," vol. 1, no. 2, pp. 95-104, 2011.

[6] R. S. Pressman, Software engineering: a practitioner's approach, 2014.

[7] M. O. Sandonís, "Keeper: A tool for management and automated deployment of CMS web services," in IEEE Nuclear Science Symposium and Medical Imaging Conference (2013 NSS/MIC), Seoul, 2013. 